\title{
Voltage-Gated Currents in Identified Rat Olfactory Receptor Neurons
}

\author{
Paul Q. Trombley ${ }^{1,2}$ and Gary L. Westbrook ${ }^{2}$ \\ 'Department of Biology and Institute of Neuroscience, University of Oregon, and 2Vollum Institute, Oregon Health \\ Sciences University, Portland, Oregon 97201
}

Whole-cell recording techniques were used to characterize voltage-gated membrane currents in neonatal rat olfactory receptor neurons (ORNs) in cell culture. Mature ORNs were identified in culture by their characteristic bipolar morphology, by retrograde labeling techniques, and by olfactory marker protein (OMP) immunoreactivity. ORNs did not have spontaneous activity, but fired action potentials to depolarizing current pulses. Action potentials were blocked by tetrodotoxin (TTX), which contrasts with the TTX-resistant action potentials in salamander olfactory receptor cells (e.g., Firestein and Werblin, 1987). Prolonged, suprathreshold current pulses evoked only a single action potential; however, repetitive firing up to $35 \mathrm{~Hz}$ could be elicited by a series of brief depolarizing pulses.

Under voltage clamp, the TTX-sensitive sodium current had activation and inactivation properties similar to other excitable cells. In TTX and $20 \mathrm{~mm}$ barium, sustained inward current were evoked by voltage steps positive to $-\mathbf{3 0} \mathrm{mV}$. This current was blocked by $\mathrm{Cd}(100 \mu \mathrm{M})$ and by nifedipine $\left(\mathrm{IC}_{50}=368 \mathrm{nM}\right)$ consistent with L-type calcium channels in other neurons. No T-type calcium current was observed. Voltage steps positive to $-20 \mathrm{mV}$ also evoked an outward current that did not inactivate during 100 -msec depolarizations. Tail current analysis of this current was consistent with a selective potassium conductance. The outward current was blocked by external tetraethylammonium but was unaffected by $C d$ or 4-aminopyridine (4-AP) or by removal of external calcium. A transient outward current was not observed.

The 3 voltage-dependent conductances in cultured rat ORNs appear to be sufficient for 2 essential functions: action potential generation and transmitter release. As a single odorant-activated channel can trigger an action potential (e.g., Lynch and Barry, 1989), the repetitive firing seen with brief depolarizing pulses suggests that ORNs do not integrate sensory input, but rather act as high-fidelity relays such that each opening of an odorant-activated channel reaches the olfactory bulb glomeruli as an action potential.

Received June 20, 1990; revised Sept. 4, 1990; accepted Sept. 19, 1990.

This work was supported by grants from NIH and the McKnight Foundation (G.L.W.) and by a predoctoral NIH training grant to the University of Oregon (P.Q.T.). We wish to thank Dr. G. Nilaver for help with immunocytochemistry, Dr. F. Margolis for the gift of antisera against olfactory marker protein, and Dr. J. Clements for the use of computer programs.

Correspondence should be addressed to Paul Q. Trombley and Gary L. Westbrook, Vollum Institute, L474, 3181 Southwest Sam Iackson Park Road, Oregon Health Sciences University, Portland, OR 97201.

Copyright (C) 1991 Society for Neuroscience $0270-6474 / 91 / 110435-10 \$ 03.00 / 0$
Olfactory receptor neurons (ORNs) function both as sensory transducers of odorant stimuli and as projection neurons relaying information to the olfactory bulb. Their morphology reflects this specialization, with ciliated dendritic knobs where odorants bind, and thin axonal projections. In amphibians, some odorants at high concentrations activate adenylate cyclase (Pace et al., 1985; Lowe et al., 1989), while cyclic nucleotides gate cation channel on the cilia, dendritic knobs, and soma of some olfactory receptor cells (Nakamura and Gold, 1987; Dionne, 1988; Labarca et al., 1988). In addition, several investigators have recently used the whole-cell patch-clamp technique to examine voltage-dependent membrane currents in amphibian ORNs (Trotier, 1986; Anderson and Hamilton, 1987; Dionne, 1987; Firestein \& Werblin, 1987; Suzuki, 1987). Much less is known about ORNs in mammals, due to their small size and inaccessibility (see, e.g., Shepherd, 1985). Attempts to obtain wholecell recording from mouse and rat ORNs have been unsuccessful, though several voltage-gated channels were seen in cellattached and excised patch recording (Maue and Dionne, 1987a; Lynch and Barry, 1989). However, the macroscopic currents underlying the excitable properties of mammalian ORNs are not well defined.

ORNs are highly sensitive transducers with single openings of odorant-gated channels sufficient to generate an action potential (Maue and Dionne, 1987a; Trotier and MacLeod, 1987; Lynch and Barry, 1989). Although ORNs appear to encode odor intensity and perhaps some aspects of odor quality, the mechanisms underlying these processes have yet to be fully described (Lancet, 1986). Modulation of voltage-gated ionic currents could contribute to initial sensory processing, as occurs in other receptor neurons such as the photoreceptor (e.g., Bader et al., 1982).

We have examined the voltage-gated ionic currents in rat ORNs in primary culture using whole-cell patch-clamp recording. Fluorescent microspheres were injected in vivo into the olfactory bulb for retrograde labeling of ORNs. This allowed positive identification of mature ORNs in the cultures. Our results demonstrate that cultured ORNs have voltage-dependent sodium, calcium, and potassium currents with properties similar to other central neurons. The limited set of membrane conductances seen in the cultured ORNs suggest that integration of sensory input may first occur in the glomerular layer of the olfactory bulb.

\section{Materials and Methods}

Cell cultures. The olfactory mucosa was dissected from 1-5-d-old rat pups that had been anesthetized with halothane and killed by decapitation. The mucosa was cut into small pieces and incubated at $37^{\circ} \mathrm{C}$ for 
45-60 min in a $\mathrm{Ca} / \mathrm{EDTA}$-buffered solution containing $20 \mathrm{U} / \mathrm{ml}$ papain (Worthington) and $1 \mathrm{~mm}$ cysteine (Sigma). Initial attempts to dissociate the olfactory mucosa without enzymes, or using other enzymes including trypsin, collagenase, and/or dispase, produced lower cell yields and were not pursued further. Following papain inactivation with bovine serum albumin $(2.5 \mathrm{mg} / \mathrm{ml})$ and trypsin inhibitor $(2.5 \mathrm{mg} / \mathrm{ml}$; Sigma Type II), the tissue was gently triturated and the cell suspension plated at a density of $\approx 50-60,000 \mathrm{cells} / \mathrm{cm}^{2}$ on a confluent layer of olfactory bulb astrocytes. The neuronal growth medium contained $95 \%$ Minimal Essential Medium (MEM; Gibco) with 5\% heat-inactivated fetal calf serum, and a nutrient supplement containing transferrin, putrescine, sodium selenite, triiodothyronine, progesterone, corticosterone, $6 \mathrm{gm} /$ liter glucose, and insulin (Guthrie et al., 1987). Astrocyte feeder layers were prepared by plating a suspension of olfactory bulb cells, prepared as described above, in a $75-\mathrm{cm}^{2}$ flask containing MEM with $10 \%$ fetal calf serum and $6 \mathrm{gm} /$ liter glucose. When the astrocytes reached confluence, they were resuspended following incubation with a $0.125 \%$ trypsin/low-Ca solution, triturated, and plated onto $35-\mathrm{mm}$ dishes coated with collagen (Vitrogen, Collagen Corp.) and poly-L-lysine (MW, 30,000-70,000; 10 $\mu \mathrm{g} /$ plate; Sigma). $5^{\prime}$-Fluoro-2-deoxyuridine and uridine (15 and $35 \mu \mathrm{g} /$ $\mathrm{ml}$, respectively) were added $1 \mathrm{~d}$ after plating neurons to prevent overgrowth of background cells. Electrophysiological recordings were usually made after $1-3 \mathrm{~d}$ in culture, but surviving ORNs could be studied for up to $2-3$ weeks.

Immunohistochemistry. Immunohistochemical procedures followed the protocol described in Nilaver and Kozlowski (1989). Primary cultures of olfactory receptor neurons were examined for immunoreactivity $3 \mathrm{~d}$ after plating using antisera prepared against olfactory marker protein (OMP; a gift from Dr. Frank Margolis, Roche Institute). Neuronal cultures were rinsed 3 times in phosphate-buffered saline and fixed in $4 \%$ buffered paraformaldehyde that was osmotically adjusted to $320 \mathrm{mOsm}$ with sucrose. The fixative was removed with 3 washes in Tris buffer, which contained $0.05 \mathrm{M}$ Tris base with $0.9 \% \mathrm{NaCl}(\mathrm{pH}, 7.6)$. Endogenous peroxidase activity was destroyed by a $30-\mathrm{min}$ incubation with $1 \%$ hydrogen peroxide in Tris buffer. Hydrogen peroxide was rinsed away with Tris buffer and incubated for $15 \mathrm{~min}$ in Tris buffer with $0.02 \%$ BSA to reduce nonspecific binding. Cultures were incubated overnight at $4^{\circ} \mathrm{C}$ in a $1: 1000$ dilution of the primary antisera (goat anti-OMP) in Tris buffer with $0.1 \%$ sodium azide. To visualize OMP-immunoreactive cells, cultures were rinsed with Tris buffer and incubated in biotinylated protein-A (1:400 dilution, $45 \mathrm{~min}$, room temperature), rinsed again with Tris buffer, and incubated in avidin-biotin complex $(1: 1000)$ prepared according to Vector Labs Protocol (Vector Labs Standard Kit) for 60 min. After a final rinse with Tris buffer, the cultures were incubated in diaminobenzidine $(0.15 \mathrm{mg} / \mathrm{ml})$ for $20-45 \mathrm{~min}$ and photographed on an inverted microscope. All procedures, unless specified, were at room temperature.

Retrograde labeling of ORNs. Neonatal rat pups (postnatal day 4-6) were injected, at 2 separate sites in each olfactory bulb, with $1.5 \mu 1$ rhodamine-labeled latex beads (1:4 dilution in sterile water; Molecular Probes, Eugene, OR). The pups were anesthetized with halothane, and the injections were made through the skin and skull using a 5- $\mu$ l Hamilton syringe with a 30 -gauge needle. The pups were returned to their mother, following recovery from anesthesia, for $48 \mathrm{hr}$ before harvesting the ORNs for cell culture; pups that failed to nurse following injections were immediately killed.

Electrophysiology. Whole-cell patch recording was performed at room temperature using standard techniques. Current-clamp and voltage-clamp recordings were made using a discontinuous voltage-clamp amplifier (Axoclamp 2A, Axon Inst.). During voltage clamp, the membrane voltage was continuously monitored to insure adequate voltage control; switching frequencies were usually $10-15 \mathrm{kHz}$. The recording chamber was perfused at $0.5-2.0 \mathrm{ml} / \mathrm{min}$ with a solution containing (mM): $\mathrm{NaCl}$, $145 ; \mathrm{KCl}, 2.5 ; \mathrm{CaCl}_{2}, 2 ; \mathrm{MgCl}_{2}, 1$; HEPES, 10; glucose, 10. The $\mathrm{pH}$ was adjusted to 7.3 with $\mathrm{NaOH}$ and the osmolarity to $325 \mathrm{mOsm}$ with sucrose. In some experiments, choline chloride was substituted for $\mathrm{NaCl}$. In experiments using $25 \mathrm{~mm}$ tetraethylammonium (TEA) and 2.5-20 $\mathrm{mm} \mathrm{K}$, ion substitutions were isoosmotic with $\mathrm{Na}$. Patch electrodes were pulled from borosilicate glass, fire polished, and filled with a solution containing (mM): $\mathrm{KMeSO}_{4}$ or $\mathrm{CsCl}, 140 ; \mathrm{MgCl}_{2}, 5$; HEPES, 10 ; $\mathrm{Na}$ ATP, 5; Na-GTP, 0.5; EGTA, 1.1 or 11 (pH, 7.2; osmolarity, 310). Electrodes had resistances of 4-6 MR.

Drugs were delivered by an array of $400-\mu \mathrm{m}$ interior diameter glass barrels (flow pipes) fed by gravity from drug reservoirs. The flow pipes were mounted on a manipulator and positioned within $100 \mu \mathrm{m}$ of the recorded neuron. Neurons were continuously perfused by onc barrcl containing the bath solution. During drug application, the flow pipes were realigned, and solenoid valves were used to shut off the control barrel and switch on the drug barrel. No attempt was made to optimize the speed of solution exchange; average exchange times were 200-500 msec. Stocks of L-glutamate, GABA, barium, tetraethylammonium, 4-aminopyridine (4-AP), and tetrodotoxin (TTX) were made in water before diluting in recording medium. Stocks of odorants were also dissolved in water; odorants were combined and used as a cocktail consisting of coniferan, citralva, isomenthone, and benzaldehyde (see Sklar et al., 1987; Lowe et al., 1989). Nifedipine was dissolved in absolute ethanol. The maximum final concentration of ethanol in the recording solution was $0.03 \%$.

Voltage protocols were generated using pCLAMP software (Axon Instr.); membrane currents were digitized and stored for later analysis on an IBM-AT. Current records were filtered at $1-3 \mathrm{kHz}$ (8-pole Bessel filter). Curve fitting was performed using nonlinear least-squares methods. Statistical results are reported as means $\pm \mathrm{SE}$.

\section{Results}

\section{Identification of ORNs in cell culture}

Cultured ORNs were identified as small bipolar cells with a long, thin axon on one end and a thick apical dendrite on the other (Fig. 1A). These were easily distinguishable from other cell types such as the supporting or respiratory epithelial cells because only ORNs had processes and fircd action potentials (e.g., Masukawa et al., 1985a; Maue and Dionne, 1987b). The dendrite in some cases had several fine cilia extending from its distal end.

As ORNs regenerate throughout the life of the animal (Graziadei and Monti Graziadei, 1979), neurons whose axon reaches the olfactory bulb are considered mature. We identified these mature cells in culture by retrograde labeling following injection of the olfactory bulb with fluorescent beads (see, e.g., Huettner and Baughman, 1986). Labeled cells were present in the cultures (Fig. 1B) and fired action potentials (Fig. 1C), consistent with behavior of mature ORNs in vivo (reviewed in Getchell, 1986). The percentage of labeled cells in cell suspensions of the olfactory mucosa ranged from $20 \%$ to $50 \%$. The morphology and electrical properties of the labeled neurons were identical to unlabeled ORNs, which were either mature cells with unlabeled axons or neuronal precursor cells that differentiated in culture (see Calof and Chikaraishi, 1989).

Cultured ORNs also were OMP immunoreactive (Fig. 1D), OMP is a specific marker for ORNs whose axons have innervated the bulb (Margolis, 1988). For the conditions used for immunohistochemistry (see Materials and Methods), approximately $10 \%$ of cells in the cultures were OMP immunoreactive, but all OMP immunoreactive cells were also labeled with fluorescent beads, consistent with identification of mature ORNs by either method. The number of fluorescent-labeled neurons appeared to decrease more rapidly with time in culture than unlabeled neurons; this may not be surprising because cutting the olfactory nerve leads to death of mature ORNs in vivo (Graziadei and Monti Graziadei, 1979; Simmons and Getchell, 1981).

\section{Chemosensitivity}

Although the primary objective of these experiments was to evaluate the voltage-dependent membrane currents of ORNs, a few cells were tested by extracellular application of a mixture of odors including coniferan, citralva, isomenthone, and benzaldehyde (0.01-1 mm). Out of 15 cells, including 5 bead-containing cells, an inward odorant-induced current was secn in only 1 cell. The low incidence of odorant responses is likely to 

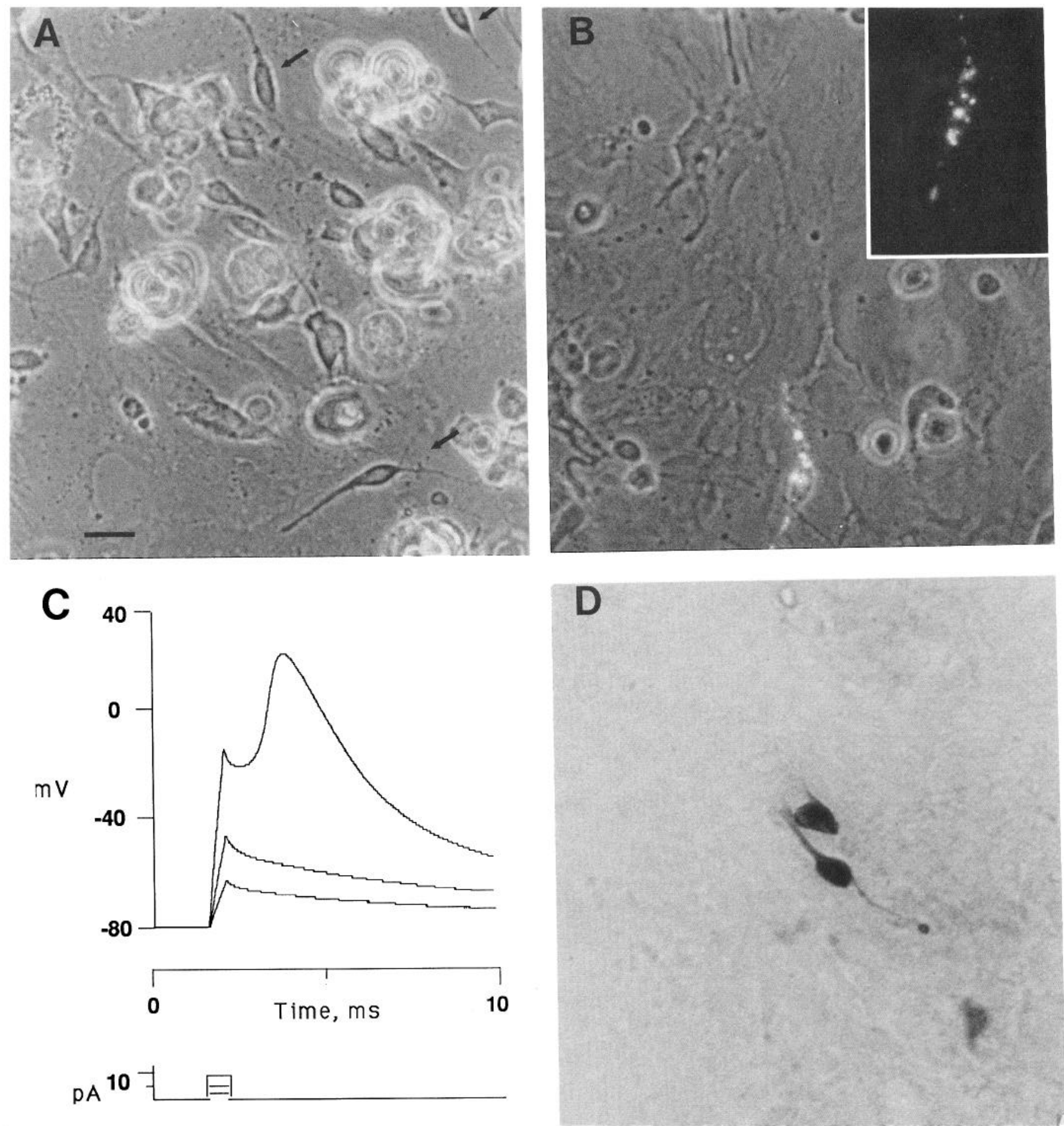

Figure 1. Identified ORNs in cell culture. $A$, Phase-contrast photomicrograph at $400 \times$ shows several receptor neurons (arrows) with typical bipolar morphology and thin axonal processes. Cilia are not visible on the dendritic knob in this photograph. $B$, Example of ORN cell body and neurite labeled with fluorescent microspheres. Microspheres were injected into olfactory bulb $48 \mathrm{hr}$ prior to dissection of the mucosa; this photograph was taken after $1 \mathrm{~d}$ in culture. The inset shows same labeled cell at $800 \times . C$, Example of action potential evoked by intracellular stimulation ( 0.5 msec, $10 \mathrm{pA}$ ) in a bead-labeled cell. $D$, Bright-field photomicrograph at $400 \times$ shows OMP immunoreactivity in 2 cultured receptor neurons. Scale bar, $20 \mu \mathrm{m}$ for $A, B, D$.

be due to the loss of cilia during our standard dissociation procedures. Similar observations have been made by Firestein and Werblin (1989) on salamander ORNs. ORNs were also unresponsive to application of the neurotransmitter agents L-gluta- mate or GABA (not shown). This contrasts with cultured olfactory bulb neurons (Frosch and Dichter, 1984; Trombley and Westbrook, 1990) and provides an additional identifying feature. 
Figure 2. Cultured ORNs have excitable properties. $A$, In an identified ORN, depolarizing current pulses $(3-18 \mathrm{pA}$, $150 \mathrm{msec}$ ) from the resting potential near $-80 \mathrm{mV}$ evoked action potentials above threshold. The 3-pA hyperpolarizing current pulses showed no rectification and demonstrate the long membrane time constant of this neuron. Suprathreshold current steps did not evoke repetitive firing. $B$, The same neuron was voltage clamped at $-80 \mathrm{mV}$; $10-\mathrm{mV}$ depolarizing voltage steps between -40 and $+20 \mathrm{mV}$ resulted in a transient inward current, followed by a sustained outward current. Current records in this and subsequent figures are leak subtracted with blanking of residual capacitative transients. Voltages shown in this and subsequent figures are the step protocols, not the recorded membrane voltage. A $\mathrm{KMeSO}_{4}$ electrode was used.
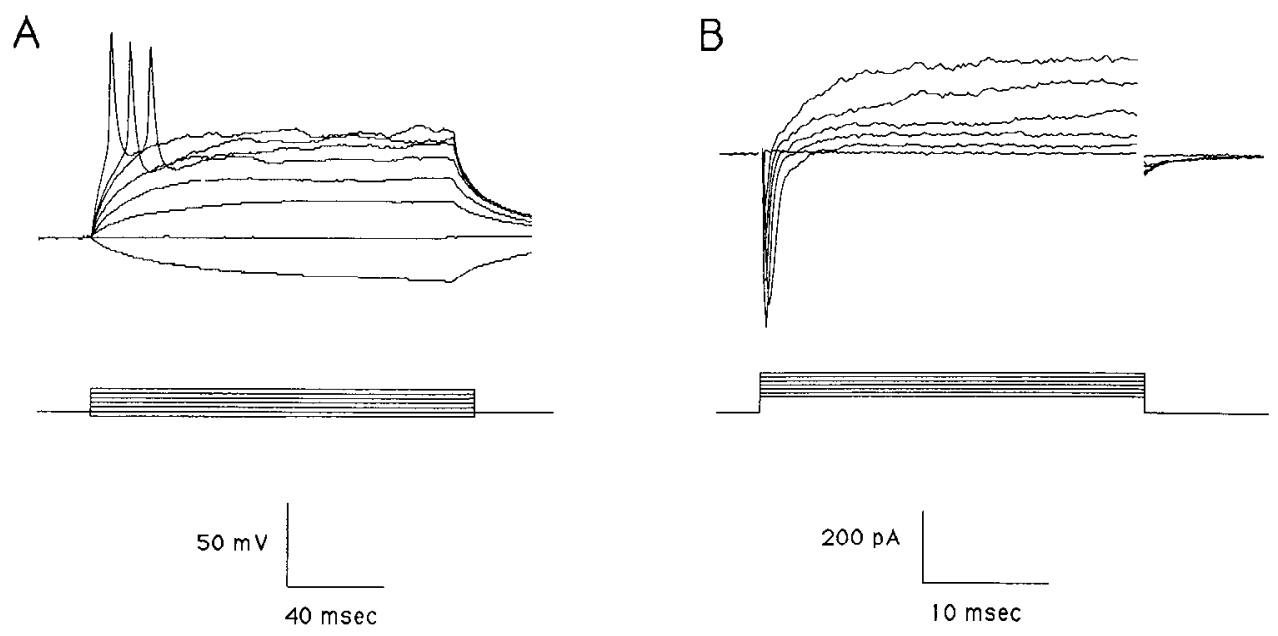

A

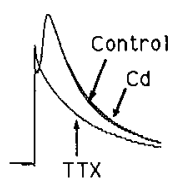

TTX

Choline

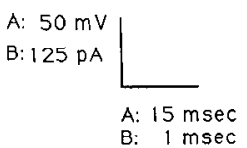

C

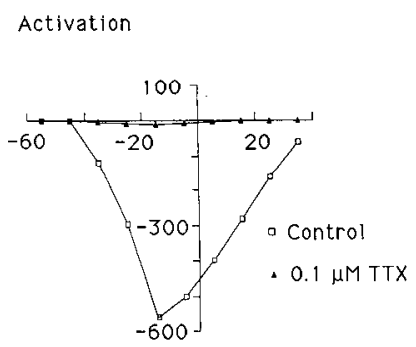

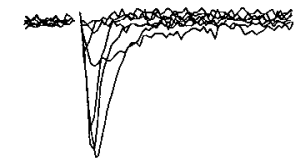
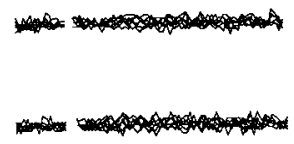

B

Cd

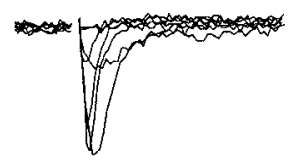

D

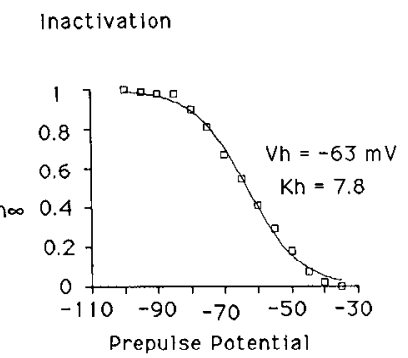

Figure 3. TTX-sensitive sodium current underlies the action potential. $A$, A 3-msec 20-pA depolarizing current pulse evoked an action potential that was unaffected by $100 \mu \mathrm{M}$ cadmium. A suprathreshold 25 -pA current pulse failed to evoke an action potential in the presence of $100 \mathrm{nM}$ TTX. $B$, Under voltage clamp, a series of $10-\mathrm{mV}$ depolarizing voltage steps from -60 to $0 \mathrm{mV}$ evoked a transient inward current, which was blocked by $100 \mathrm{nM}$ TTX or by choline substitution for sodium, but not by $100 \mu \mathrm{M}$ cadmium. $C$, The current-voltage relationship of the sodium current for one receptor neuron shows complete block by $100 \mathrm{~nm}$ TTX. Holding potential was $-80 \mathrm{mV}$. $D$, Steady-state activation curve for the sodium current for 5 neurons was obtained from normalized peak current amplitudes of steps to $-20 \mathrm{mV}$ after a $250-\mathrm{msec}$ prepulse to the voltage indicated. The curve is a least-squares fit to $h=1 /[1+$ $\left.\exp \left(V-V_{h}\right) / K_{h}\right]$, where $V_{h}$ is the half inactivation value $(h=0.5)$, and $K_{h}$ is a constant.

\section{Membrane excitability}

Stable whole-cell recordings were obtained from ORNs after 1$3 \mathrm{~d}$ in culture; with potassium-containing patch solutions, the resting potentials were near $-80 \mathrm{mV}$. With voltage recording, depolarizing current steps evoked overshooting action potentials with half-durations of 2-3 msec (Fig. 2A). However, only a single action potential could be generated even with long suprathreshold depolarizing current injections. The input resistance near the resting membranc potential was equal to or greater than the seal resistance of 5-10 G $\Omega$, similar to values reported for tiger salamander ORNs (Trotier, 1986; Firestein and Werblin, 1987; Suzuki, 1987). The extremely high input resistance and negative membrane potential in rat ORNs suggest that there are only a few "leakage" potassium channels open at rest. Under voltage clamp, a series of $10-\mathrm{mV}$ depolarizing voltage steps evoked a transient inward current, which activated at membrane potentials positive to $-45 \mathrm{mV}$, and an outward current, which did not inactivate with step durations of $40-100$ msec (Fig. 2B).

\section{TTX-sensitive inward current underlies the action potential}

Action potentials, evoked in ORNs with short-duration (3-msec) depolarizing current pulses, were extremely sensitive to low concentrations of TTX. This contrasts with the action potential current in tiger salamander ORNs, which is TTX resistant (Firestein and Werblin, 1987). As shown in Figure $3 A, 100$ nM TTX completely blocked the action potential, while $100 \mu \mathrm{M} \mathrm{Cd}$ had no effect $(n=10)$. These results demonstrate that the action potential in cultured ORNs results primarily from sodium influx.

To examine the kinetic properties of the TTX-sensitive current, ORNs were voltage clamped at $-80 \mathrm{mV}$ using Cs-containing patch pipettes to block outward currents. Voltage steps in $10-\mathrm{mV}$ increments positive to $-45 \mathrm{mV}$ evoked a rapidly inactivating inward current; steps to -45 or $-35 \mathrm{mV}$ were characteristically slower in onset and decay. However, in some cells, inward currents began abruptly after a delay, suggesting inadequate space clamp due to activation of channels in poorly clamped axonal regions; such cells were not analyzed further. The transient inward current was completely eliminated by flow 
A
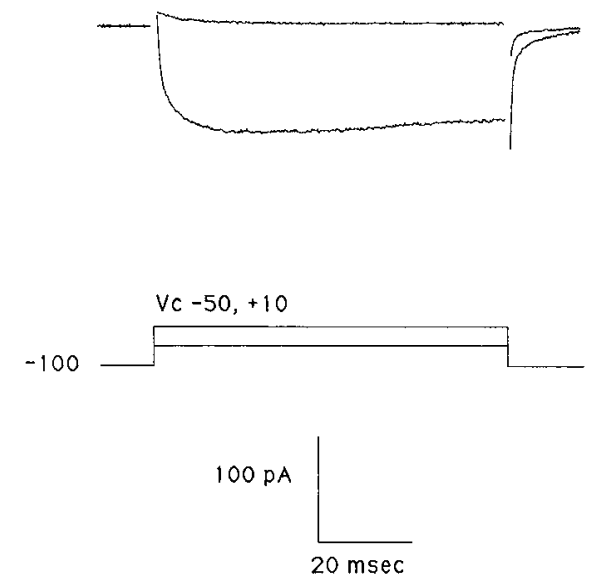

B

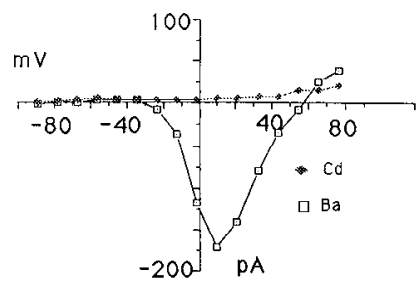

Figure 4. Only high-threshold calcium channels were present in ORNs. $A$, Under voltage clamp, a 75-msec depolarizing voltage step to $+10 \mathrm{mV}$ from a holding potential of $-100 \mathrm{mV}$ evokes a sustained inward current carried by barium. However, a depolarizing voltage step from -100 to $-50 \mathrm{mV}$ failed to evoke an inward current. The external solution contained $10 \mathrm{~mm} \mathrm{Ba}, 300$ nM TTX, and 15 mM TEA. $B$, The current-voltage relationship of the peak inward barium current. The current was competely blocked by application of 100 $\mu \mathrm{M}$ cadmium. $C$, Repeated voltage jumps to $+10 \mathrm{mV}$ during a $30-\mathrm{min}$ whole-cell recording demonstrate the slow rundown of the barium current. Both $\mathrm{Cd}(100 \mu \mathrm{M})$ and Nifedipine $(1 \mu \mathrm{M})$ reversibly blocked the current. $\mathrm{A} \mathrm{CsCl}$ patch solution with $5 \mathrm{~mm} \mathrm{Mg-ATP}$ was used. pipe applications of $100 \mathrm{nM}$ TTX or by substitution of choline for external $\mathrm{Na}$, but was unaffected by $100 \mu \mathrm{M}$ Cd (Fig. 3B). The current-voltage relationship of the sodium current for one neuron is shown in Figure $3 C$. The inward current peaked near $-15 \mathrm{mV}$ and had a peak amplitude of $580 \mathrm{pA}$. Similar results were obtained in 9 neurons. The TTX-sensitive Na current in ORNs showed typical inactivation propertics. Stcady-statc inactivation was determined for steps to $-20 \mathrm{mV}$ following a 250 msec prepulse and normalized to the peak current evoked from a prepulse potential of $-100 \mathrm{mV}$. For 5 neurons, the halfinactivation voltage was $-63 \mathrm{mV}$ and $K_{h}$ was 7.8 (Fig. $3 D$ ).

\section{High-threshold calcium current}

In the presence of TTX, a voltage-dependent calcium current was also observed in cultured ORNs. This current was often less than $20 \mathrm{pA}$ in $2 \mathrm{~mm} \mathrm{[Ca}]_{o}$; therefore, for ease of analysis, barium ( $10 \mathrm{~mm}$ ) was substituted for external calcium. As shown in Figure $4 A$, inward barium currents were evoked by a step to $+10 \mathrm{mV}$ from a holding potential of $-100 \mathrm{mV}$. The current had a rapid onset and showed little inactivation during the 75msec voltage step. A voltage step to $-50 \mathrm{mV}$ from a holding potential of $-100 \mathrm{mV}$ did not evoke an inward current (Fig. $4 A$ ). This is consistent with the presence of high-threshold (L-type), but not with low-threshold (T-type) calcium channels (Bean, 1985; Nowycky et al., 1985). The barium current activated near $-35 \mathrm{mV}$, peaked at $+10 \mathrm{mV}$, and reversed at +60 $\mathrm{mV}$ (Fig. $4 B$ ); the outward current at positive membrane potentials presumably reflects outward movement of cesium ions through the channel (Fenwick et al., 1982; Lee and Tsien, 1982). The barium current was reversibly blocked by flow pipe application of $100 \mu \mathrm{M}$ cadmium (Fig. $4 B, C$ ) and by $1 \mu \mathrm{M}$ nifedipine (Fig. 4C), consistent with the dihydropyridine sensitivity of L-type calcium channels (Bean, 1989). The barium current showed rundown even in the presence of $5 \mathrm{~mm} \mathrm{Mg-ATP}$; however, measurable current could often be recorded for up to 30 $\min$ (Fig. 4C).
The L-type calcium current in cultured ORNs was quite sensitive to dihydropyridines. As shown in Figure $5 A$, nifedipine $(1 \mu \mathrm{M})$ blocked more than $85 \%$ of the barium current activated by a voltage step to $+10 \mathrm{mV}$. The concentration-response curve for the effects of nifedipine on the barium current on 5 neurons is shown in Figure $5 B$. The $\mathrm{IC}_{50}$ for nifedipine was $368 \mathrm{~nm}$. Unlike cardiac calcium channels (Bean, 1989), nifedipine block of ORN calcium channels was not voltage sensitive.

\section{The voltage-dependent potassium current}

Most neurons have a diverse set of potassium channels that have been categorized by their kinetics, voltage dependence, and pharmacology. Maue and Dionne (1987a) reported 4 potassium channels in excised membrane patches from mouse ORNs, including 2 calcium-dependent potassium conductances. Outward currents in rat ORNs were examined in the presence of $2 \mathrm{~mm}[\mathrm{Ca}]_{o}$ and TTX to block sodium currents. Intracellular calcium was only loosely buffered with $1.1 \mathrm{~mm}$ EGTA to permit the occurrence of calcium transients (see, e.g., Mayer et al., 1987). As shown in Figure 6, a large outward current could be evoked in cultured rat OKNs with depolarizing voltage steps. The outward current began to activate near $-30 \mathrm{mV}$ from a holding potential of $-80 \mathrm{mV}$ and increased stceply bcyond -10 $\mathrm{mV}$. Similar results were obtained in 16 neurons. The activation rate was voltage dependent, with the current reaching a peak within $5-10 \mathrm{msec}$ with steps to $+40 \mathrm{mV}$. The current showed little inactivation, at least for step durations up to $100 \mathrm{msec}$, and was reversibly blocked with $25 \mathrm{mM}$ TEA, but unaffected by $100 \mu \mathrm{M}$ cadmium (Fig. 6A,B). This is similar to the delayed rectifier current, first described in squid axon and seen in many excitable cells (Hille, 1984).

To examine the ionic basis of the outward current, a family of peak tail current amplitudes were measured at different membrane potentials after brief voltage step to $+20 \mathrm{mV}$ to activate the current fully. With $[\mathrm{K}]_{o}=145 \mathrm{~mm}$ and $[\mathrm{K}]_{i}=20 \mathrm{~mm}$, the tail current reversed near $-50 \mathrm{mV}$, the reversal potential pre- 
A

Figure 5. Inward barium current was dihydropyridine sensitive. $A$, Nifedipine $(1 \mu \mathrm{M})$ reduced the barium current from 175 to $25 \mathrm{pA}$. The voltage step was from -100 to $+10 \mathrm{mV}$. $B$, Nifedipine (30-3000 nM) blocked peak barium currents in a dose-dependent manner. Individual points are the mean current $( \pm$ SE) for 5 cells taken as the average of 10 sample points at peak current. The current amplitudes obtained during nifedipine application were normalized for each cell. The curve is a nonlinear least-squares fit to the equation $I=I_{\text {control }}-\left\{[A] /\left([A]+\mathbf{I C}_{50}\right)\right\}$, where $I_{\text {control }}$ is the current in the absence of nifedipine, $[A]$ is the concentration of nifedipine, and $\mathrm{IC}_{50}$ is the concentration of nifedipine that inhibited $50 \%$ of the current.
B

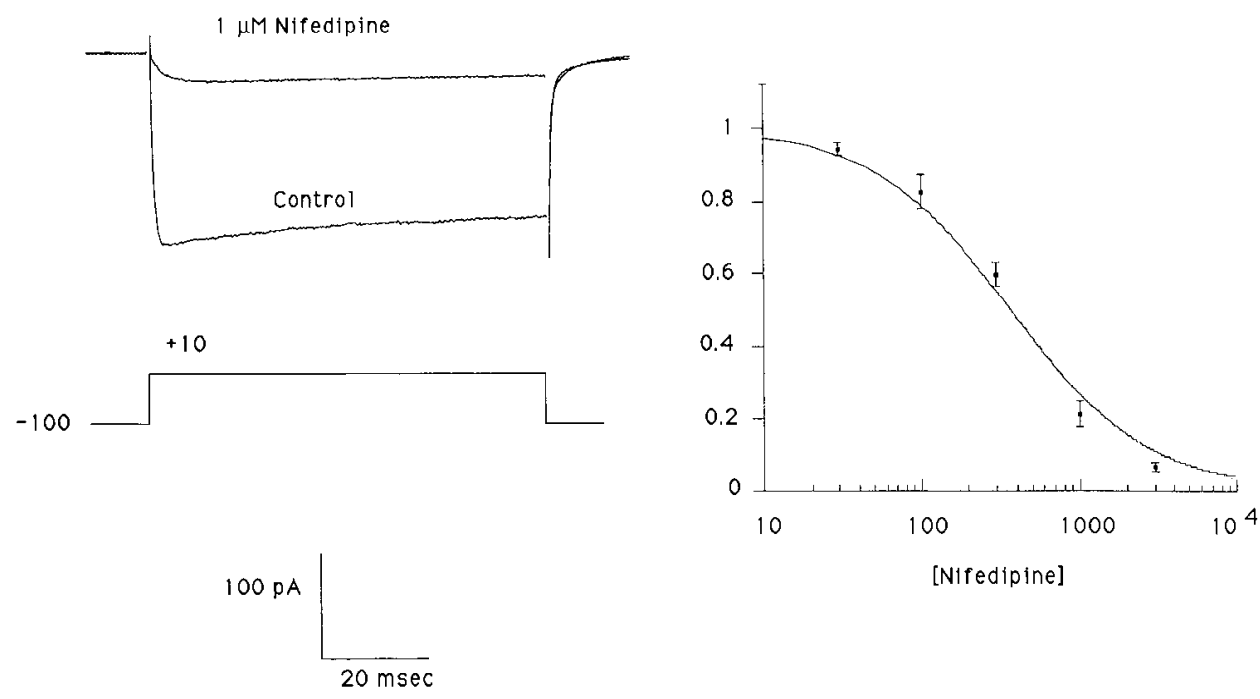

dicted for a selective potassium permeability by the Nernst equation (Fig. 7A). The tail current amplitudes, plotted as a function of the command potential for different external potassium concentrations, are shown in Figure $7 B$. As expected, increases in $[\mathrm{K}]_{o}$ resulted in a depolarizing shift of the tail current reversal potential. The reversal potentials, plotted as a function of external potassium concentration, generated a slope of 54 ( $n$ $=5$; Fig. 7C).

Maue and Dionne (1987a) report a 130-pS channel in excised patches from mouse ORNs that is dependent on external calcium concentration and voltage. However, a macroscopic Caactivated potassium current was not apparent in our initial ex-

A

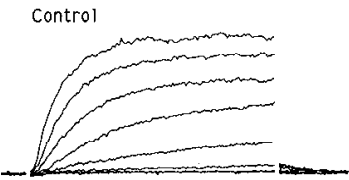

25 mM TEA
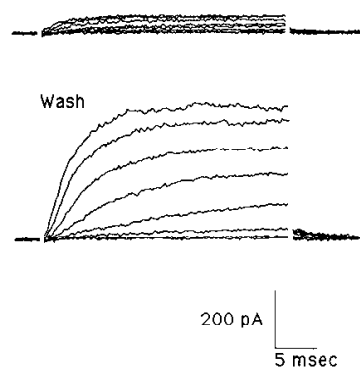

Figure 6. Voltage-dependent outward current in ORNs was TEA sensitive. $A$, A series of $10-\mathrm{mV}$ depolarizing voltage steps between -30 and $+40 \mathrm{mV}$ from a holding potential of $-80 \mathrm{mV}$ evoked a sustained outward current that was reversibly blocked by TEA (25 mM). $B$, Current-voltage relationship for the sustained outward current for the neuron shown in $A$, measured at the end of a $30-\mathrm{msec}$ voltage step. TEA $(25 \mathrm{~mm}$ ) reduced the current to $13 \%$ of control at $+40 \mathrm{mV}$, whereas Cd $(100 \mu \mathrm{M})$ had no significant effect. periments, because cadmium had no effect on the outward current (see Fig. $6 B$ ). This was confirmed by removing external calcium. As shown in Figure $8 A, 75-\mathrm{msec}$ voltage steps to -10 $\mathrm{mV}$ and $+10 \mathrm{mV}$ evoked outward currents (Fig. 8A), which were not reduced by perfusion with a solution containing $0 \mathrm{~mm}$ $\mathrm{Ca}$ and $0.5 \mathrm{~mm}$ EGTA ( $n=5$; Fig. $8 B$ ). The slight increase in the current amplitude is probably due to relief from a screening effect of $2 \mathrm{~mm}$ external calcium. The lack of a macroscopic $\mathrm{Ca}$ activated potassium current was not due to washout of the voltage-dependent calcium current because a $75-\mathrm{msec}$ voltage step to $+20 \mathrm{mV}$ evoked an inward calcium current in the same cell following inclusion of $25 \mathrm{~mm}$ TEA and $10 \mathrm{~mm}$ calcium in the external solution (Fig. 8C).

Although most neurons including cultured olfactory bulb neurons have a transient outward current $\left(I_{A}\right)$ blocked by 4-AP (e.g., Rogawski, 1985), no transient outward current was seen in the cultured ORNs (Fig. 9A,B). A depolarizing voltage step to +20 $\mathrm{mV}$ from a holding potential of $-80 \mathrm{mV}$ evoked only a sustained TEA-sensitive outward current in rat ORNs (Fig. 9A), whereas an identical voltage step in a cultured olfactory bulb neuron evoked both a transient and a sustained outward current. 4-AP ( $1 \mathrm{mM}$ ) selectively blocked the transient component in the bulb neuron, but had no effect on the outward current in the ORN.

\section{Firing patterns of cultured receptor neurons}

Extracellular recording from the olfactory nerve clearly demonstrates repetitive firing that increases with odorant concentration (Getchell, 1977; see also Lancet, 1986). Repetitive firing has been reported, in some cases with prolonged depolarizing current pulses, in intracellular recording from salamander ORNs. However, the repeated action potentials were often attenuated (e.g., Masukawa et al., 1985b; Anderson and Hamilton, 1987; Hedlund et al., 1987). Cultured rat ORNs fired only a single action potential to long depolarizing pulses, as shown for one neuron in Figure $10 \mathrm{~A}$. However, repetitive firing was seen if trains of brief current pulses were used to stimulate action potentials (Fig. 10B,C). Similar results were seen on 6 cells. The maximum firing rate was approximately $40 \mathrm{~Hz}$, comparable to firing rates of olfactory nerve units to odorant stimuli in vivo (Getchell, 1986). 

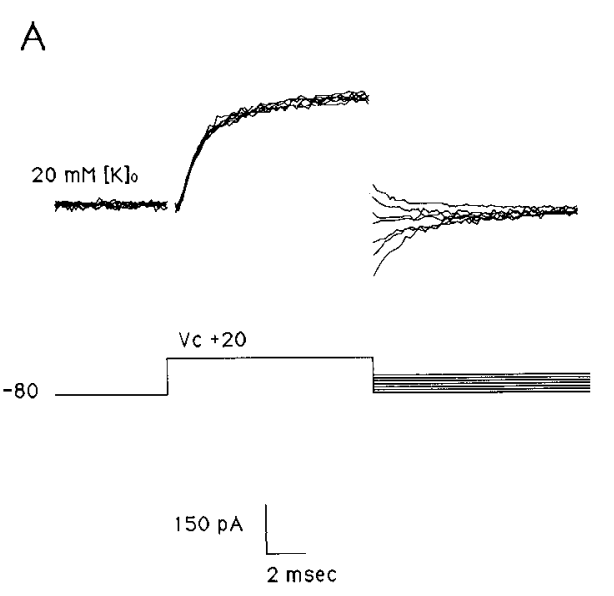

\section{Discussion}

Our results provide an initial characterization of the macroscopic currents in mammalian ORNs in vitro. Three voltagegated currents were seen in cultured rat ORNs: a TTX-sensitive sodium current, an L-type calcium current, and a delayed rectifier potassium current. This limited set of conductances would seem to allow only modest integrative and frequency-coding capabilities for ORNs, compared to other central neurons.

\section{Action potential currents in cultured rat ORNS}

The sodium and potassium current in rat ORNs in culture had properties similar to many excitable cells, including the squid axon (Hodgkin and Huxley, 1952; Hille, 1984). The outward potassium current fits well into the class of delayed rectifier $K$ channels that account for the rapid repolarization necessary for the brief action potentials seen in ORNs. The sodium current
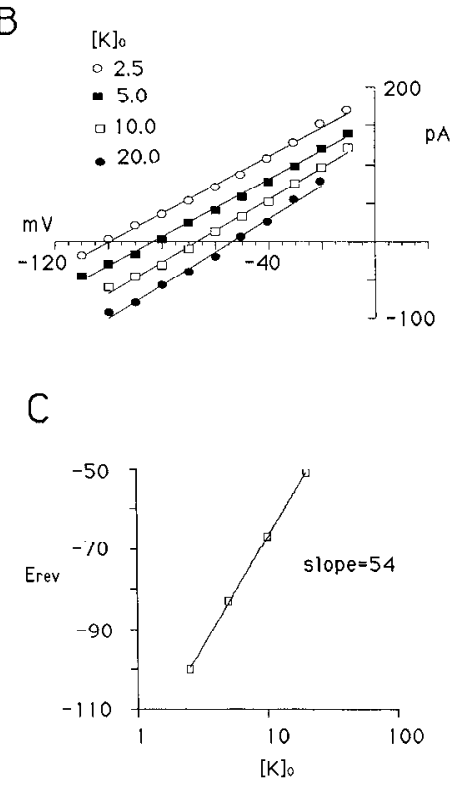

Figure 7. Sustained outward current was potassium selective. $A$, Tail currents were evoked with a double-pulse protocol as shown. The membrane voltage was stepped back to potentials between -20 and $-80 \mathrm{mV}$ following a $10-\mathrm{msec}$ voltage step to $+20 \mathrm{mV}$. Holding potential was $-80 \mathrm{mV}$. In 20 mM external $\mathrm{K}$, the tail current reversed near $-50 \mathrm{mV}$. B, Current-voltage relationship for tail currents at 4 external potassium concentrations between 2.5 and $20 \mathrm{~mm}$. Tail current amplitudes were measured $400 \mu$ sec after the voltage step. $C$, The tail current reversal potential plotted versus the external potassium concentration had a slope close to the expected value of 58 for a selective potassium permeability. Data are least-squares fit to the mean values from 5 neurons. was completely blocked by nanomolar concentrations of TTX and was responsible for the upstroke of the action potential. The steady-state half-inactivation voltage was $-63 \mathrm{mV}$, with full inactivation at membrane potentials of $-40 \mathrm{mV}$. Similar inactivation has been reported in salamander ORNs (Firestein and Werblin, 1987). The low resting potentials reported in earlier intracellular studies of bullfrog and salamander ORNs (e.g., Anderson and Hamilton, 1987; Suzuki, 1987) probably reflect the difficulty of microelectrode recording in these cells; otherwise, the sodium current would be inactivated. Consistent with this, inactivation of action potentials was also seen in cell-attached recording from rat ORNs at positive patch potentials (Lynch and Barry, 1989).

The transient inward current in tiger salamander ORNs is sodium dependent but highly TTX resistant and is blocked by 5-10 mM cobalt (Trotier, 1986; Firestein and Werblin, 1987). Because the kinetics of the sodium current in salamanders are
A
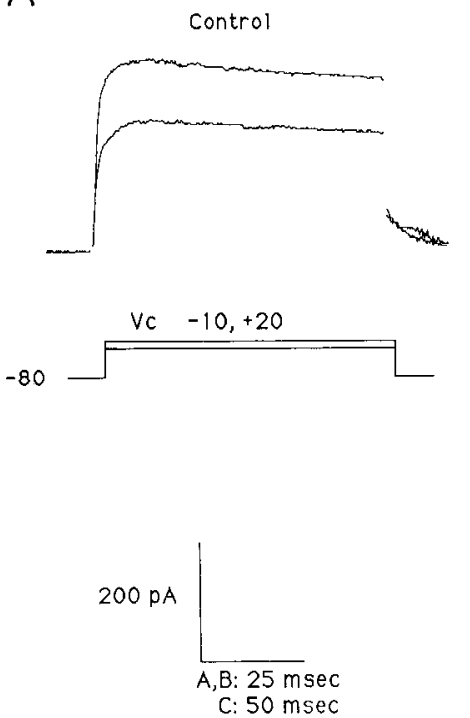

\section{C}

$10 \mathrm{mM} \mathrm{Ca} / 25 \mathrm{mM}$ TEA

B
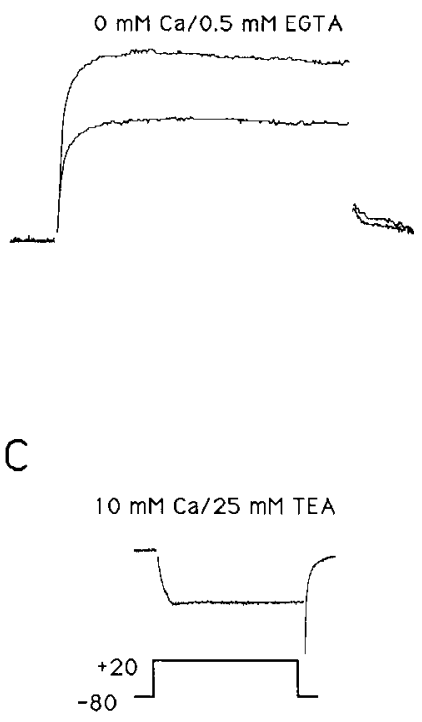

Figure 8. No macroscopic Ca-activated $\mathrm{K}$ current was present. $A$, In 2 mM external $\mathrm{Ca}$, 75-msec depolarizing voltage steps to -10 and $+20 \mathrm{mV}$ evoked an outward current. $B$, Perfusion of the same neuron with a solution containing $0 \mathrm{Ca}$ and $0.5 \mathrm{~mm}$ EGTA did not reduce the outward current. $C$, Despite the lack of a Ca-dependent outward current, external perfusion of the same cell with TTX, $10 \mathrm{~mm} \mathrm{Ca}$, and 25 mM TEA revealed a voltage-dependent calcium current evoked by a $75-\mathrm{msec}$ step from -80 to $+20 \mathrm{mV}$. 
A

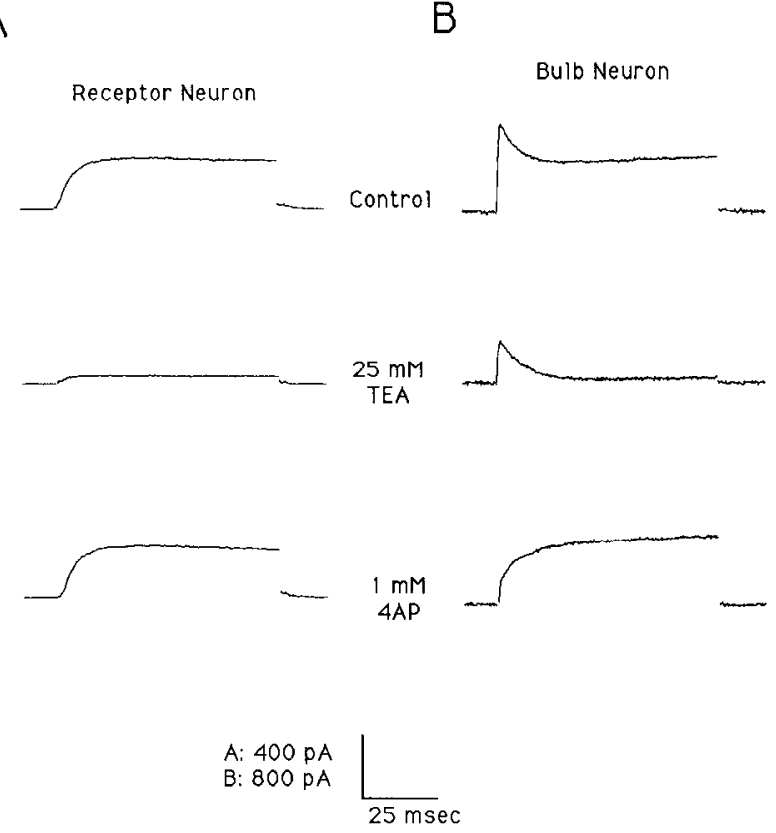

Figure 9. Olfactory bulb neurons but not receptor neurons have 4-APsensitive transient outward current. $A$, In a receptor neuron, the outward current evoked by a voltage step from -80 to $+20 \mathrm{mV}$ was blocked by $25 \mathrm{~mm}$ TEA, but was unaffected by $1 \mathrm{~mm}$ 4-AP. $B$, Olfactory bulb neurons, grown under identical culture conditions, had transient and sustained outward currents. TEA blocked the sustained current and revcaled a transient component that was blocked by $1 \mathrm{mM} 4-\mathrm{AP}$, consistent with the presence of $I_{A}$ in the bulb neuron. The holding potential was $-80 \mathrm{mV}$.

similar to those reported here, the channels are likely to be quite similar in function and perhaps even in structure; for example, a single point mutation in the rat brain sodium channel II causes a 1000-fold reduction in TTX sensitivity (Noda et al., 1989). The species difference may be related to production of TTX by some salamanders (but not Ambystoma tigrinum), making TTXresistant sodium channels a necessity (see Hille, 1984).

Neither the action potential nor the transient inward current was affected by cadmium, suggesting that there is no calcium component to the action potential. The calcium current in rat ORNs was of the high threshold or $\mathrm{L}$ type based on its activation and sensitivity to nifedipine (Fox et al., 1987; Bean, 1989) and is presumably the calcium channel required for transmitter release at ORN nerve terminals. No T-type calcium current was present. Although induction of $\mathrm{T}$ currents in cultured cortical astrocytes by some lots of sera has been reported (Barres et al., 1989), no T current was seen using either horse sera or several lots of fetal calf sera in the growth medium.

\section{Comparison to other receptor cells}

Although voltage-gated membrane currents can modulate the receptor potential in other receptor neurons, such as photoreceptors and hair cells (e.g., Bader et al., 1982; Lewis and Hudspeth, 1982), cultured rat ORNs appear to lack the potassium channels such as the $I_{A}$ and Ca-dependent $\mathrm{K}$ currents, which serve critical modulatory roles in other neurons (e.g., Levitan and Kaczmarek, 1987). Both inactivating and calcium-dependent $\mathrm{K}$ currents have been reported in ORNs from the lobster (Anderson and Ache, 1985), salamander (Firestein and Werblin,
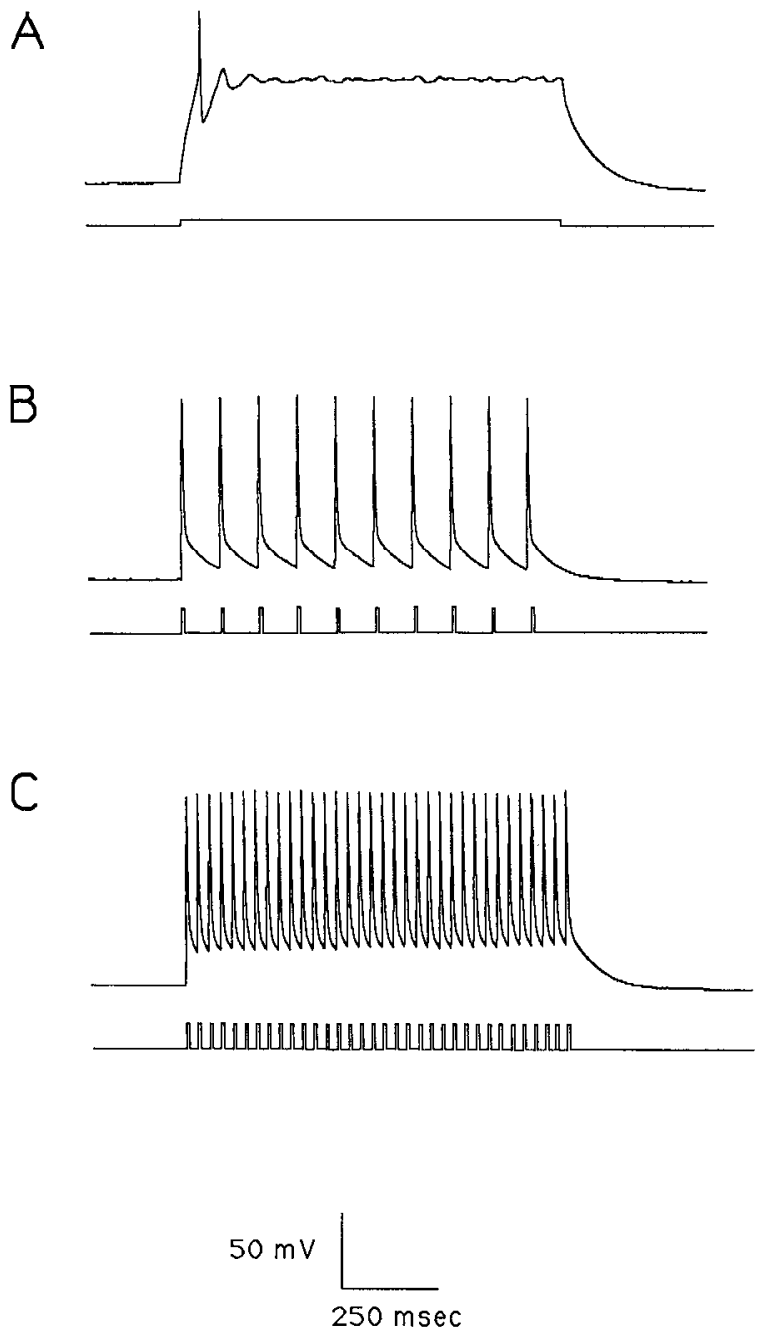

Figure 10. Receptor neurons fired repetitive action potentials to series of brief depolarizing current pulses. $A$, A 1 -sec depolarized current pulse (15 pA) evoked only a single action potential. The resting potential was $-80 \mathrm{mV} . B$ and $C$, A series of 25 -pA current pulses evoked repetitive firing at $10 \mathrm{~Hz}(B)$ and $35 \mathrm{~Hz}(C)$. $\mathrm{A} \mathrm{KMeSO}_{4}$ patch solution was used.

1987), and Necturus (Dionne, 1987) and in single-channel recording from the mouse (Maue and Dionne, 1987a). We have no simple explanation for this discrepancy. Acquired $\mathrm{Ca}$ sensitivity of $K$ channels can occur in some neurons during development (Blair and Dionne, 1985). However, the lack of certain voltage-gated currents is unlikely to be due to use of neonatal animals because ORNs undergo continuous renewal every 30 $60 \mathrm{~d}$ (Simmons and Getchell, 1981), though neurogenesis during development is not necessarily identical to neurogenesis during regeneration. It is also conceivable that buffering of intracellular calcium prevented the appearance of macroscopic Ca-dependent potassium conductances, though the low concentrations of intracellular EGTA used in these experiments do not eliminate intracellular $\mathrm{Ca}$ transients in other neurons (e.g., Mayer et al., 1987). It is interesting that Ca-K channels were also absent in whole-cell recording from isolated taste receptors, but present in intact lingual epithelium (Kinnamon and Roper, 1988). Correlation of macroscopic currents with single-channel recording will be necessary to resolve this issue for rat ORNs. 


\section{Frequency encoding in olfactory receptor neurons}

Cultured ORNs could only be induced to fire repetitive action potentials with trains of brief current pulses. This behavior differs from some receptor cells, where graded increases in stimulation result in increased firing. This apparent lack of encoding could be due to some aspect of our experimental conditions. For example, immature salamander ORNs following olfactory nerve transection did not show repetitive firing, though mature cells did (Masukawa et al., 1985b). However, it is interesting that single odorant-activated channels can trigger action potentials, but long channel openings do not evoke repetitive firing (Lynch and Barry, 1989). This might suggest a situation where each channel opening is transmitted to the olfactory bulb glomeruli as a single action potential. In its most extreme form, this mode of firing suggests that, following transduction of the odorant stimulus, the receptor neuron acts primarily as a digital relay for transmission of sensory input to the olfactory bulb. Sensory integration by individual receptor neurons may be less important than the integration inherent in the convergence of 50 million olfactory receptor neurons onto 2000 olfactory glomeruli (Allison, 1953).

\section{References}

Allison AC (1953) The morphology of the olfactory system in the vertebrates. Biol Rev 28:195.

Anderson PAV, Ache BW (1985) Voltage- and current-clamp recordings of the receptor potential in olfactory receptor cells in situ. Brain Res 338:273-280.

Anderson PAV, Hamilton KA (1987) Intracellular recordings from isolated salamander olfactory receptor neurons. Neuroscience 21:167173.

Bader CR, Bertrand D, Schwartz EA (1982) Voltage-activated and calcium-activated currents studied in solitary rod inner segments from the salamander retina. J Physiol (Lond) 331:253-284.

Barres BA, Chun LLY, Corey DP (1989) Calcium currents in cortical astrocytes: induction by cAMP and neurotransmitters and permissive effect of serum factors. J Neurosci 9:3169-3175.

Bean BP (1985) Two kinds of calcium channels in canine atrial cells. J Gen Physiol 86:1-30.

Bean BP (1989) Classes of calcium channels in vertebrate cells. Annu Rev Physiol 51:367-384.

Blair LAC, Dionne VE (1985) Developmental acquisition of $\mathrm{Ca}^{2+}$ sensitivity by $\mathrm{K}^{+}$channels in spinal neurons. Nature 315:329-331.

Calof AL, Chikaraishi DM (1989) Analysis of neurogenesis in a mammalian neuroepithelium: proliferation and differentiation of an olfactory neuron precursor in vitro. Neuron 3:115-127.

Dionne VE (1987) Acid induced responses from Necturus olfactory receptor neurons. Biophys J 51:35a.

Dionne VE (1988) How do you smell? Principle in question. Trends Neurosci 11:188-189.

Fenwick EM, Marty A, Neher E (1982) Sodium and calcium channels in bovine chromaffin cells. J Physiol (Lond) 331:599-635.

Firestein S, Werblin FS (1987) Gated currents in isolated olfactory receptor neurons of the larval tiger salamander. Proc Natl Acad Sci USA 84:6292-6296.

Firestein S, Werblin FS (1989) Odor-induced membrane currents in vertebrate-olfactory receptor neurons. Science 244:79-82.

Fox AP, Nowycky MC, Tsien RW (1987) Kinetic and pharmacological properties distinguishing three types of calcium currents in chick sensory neurones. J Physiol (Lond) 394:149-172.

Frosch MP, Dichter MA (1984) Physiology and pharmacology of olfactory bulb neurons in dissociated cell culture. Brain Res 290:321332.

Getchell TV (1977) Analysis of intracellular recordings from salamander olfactory epithelium. Brain Res 123:275-286.

Getchell TV (1986) Functional properties of vertebrate olfactory receptor neurons. Physiol Rev 66:772-818

Graziadei PPC, Monti Graziadei GA (1979) Neurogenesis and neuron regeneration in the olfactory system of mammals. I. Morphological aspects of differentiation and structural organization of the olfactory sensory neurons. J. Neurocytol 8:1-17.

Guthrie PB, Brenneman DE, Neale EA (1987) Morphological and biochemical differences expressed in separate dissociated cell cultures of dorsal and ventral halves of the mouse spinal cord. Brain Res 420: 313-323.

Hedlund B, Masukawa LM, Shepherd GM (1987) Excitable properties of olfactory receptor neurons. J Neurosci 7:2338-2343.

Hille B (1984) Ionic channels of excitable membranes. Sunderland, MA: Sinauer

Hodgkin AL, Huxley AF (1952) The components of membrane conductance in the giant axon of Loligo. J Physiol (Lond) 116:473-496.

Huettner JE, Baughman RW (1986) Primary culture of identified neurons from the visual cortex of postnatal rats. J Neurosci 6:3044-3060

Kinnamon SC, Roper SD (1988) Membrane properties of isolated mudpuppy taste cells. J Gen Physiol 91:351-371.

Labarca P, Simon SA, Anholt RR (1988) Activation by odorants of a multistate cation channel from olfactory cilia. Proc Natl Acad Sci USA 85:944-947.

Lancet D (1986) Vertebrate olfactory reception. Annu Rev Ncurosci 9:329-355.

Lee KS, Tsien RW (1982) Reversal of current through calcium channels is dialyzed single heart cells. Nature 297:498-501.

Levitan IB, Kaczmarek LK (1987) Ion currents and ion channels: substrates for neuromodulation. In: Neuromodulation. The biochemical control of neuronal excitability (Kaczmarek LK, Levitan IB, eds), pp 18-38. New York: Oxford UP.

Lewis RS, Hudspeth AJ (1982) Voltage and ion-dependent conductances in solitary vertebrate hair cells. Nature 304:538-541.

Lowe G, Nakamura T, Gold GH (1989) Adenylate cyclase mediates olfactory transduction for a wide variety of odorants. Proc Natl Acad Sci USA 86:5641-5645.

Lynch JW, Barry PH (1989) Action potentials initiated by single channels opening in a small ncuron (rat olfactory receptor). Biophys J 55: 755-768.

Margolis FL (1988) Molecular cloning of olfactory-specific gene products. In: Molecular neurobiology of the olfactory system (Margolis FL, Getchell TV, eds), pp 237-265. New York: Plenum.

Masukawa LM, Hedlund B, Shepherd GM (1985a) Electrophysiological properties of identified cells in the in vitro olfactory epithelium of the tiger salamander. J Neurosci 5:128-135.

Masukawa LM, Hedlund B, Shepherd GM (1985b) Changes in the electrical properties of olfactory epithelial cells in the tiger salamander after olfactory nerve transection. J Neurosci 5:136-141.

Maue RA, Dionne VE (1987a) Patch-clamp studies of isolated mouse olfactory receptor neurons. J Gen Physiol 90:95-125.

Maue RA, Dionne VE (1987b) Preparation of isolated mouse olfactory receptor neurons. Pfluegers Arch 409:244-250.

Mayer ML, MacDermott AB, Westbrook GL, Smith SJ, Barker JL (1987) Agonist- and voltage-gated calcium entry in cultured mouse spinal cord neurons under voltage clamp measured using arsenazo III. J Neurosci 7:3230.

Nakamura T, Gold GH (1987) A cyclic nucleotide-gated conductance in olfactory receptor cilia. Nature $325: 442-444$.

Nilaver G, Kozlowski GP (1989) Comparison of the PAP and ABC immunocytochemical techniques. In: Techniques in immunocytochemistry, Vol 4 (Bullock GR, Pertrusz P, eds), pp 199-215. San Diego: Academic.

Noda M, Suzuki H, Numa S, Stühmer W (1989) A single point mutation confers tetrodotoxin and saxitoxin insensitivity on the sodium channel II. FEBS Lett 259:213-216.

Nowycky MC, Fox AP, Tsien RW (1985) Three types of neuronal calcium channels with different calcium agonist sensitivity. Nature 316:440-442.

Pace U, Hanski E, Salomon Y, Lancet D (1985) Odorant-sensitive adenylate cyclase may mediate olfactory reception. Nature 316:255258 .

Rogawski MA (1985) The A-current: how ubiquitous a feature of excitable cells is it? Trends Neurosci 8:214-219.

Shepherd GM (1985) The olfactory system: the uses of neural space for a non-spatial modality. In: Contemporary sensory neurobiology (Correia MJ, Perachio AA, eds), pp 99-116. New York: Liss.

Simmons PA, Getchell TV (1981) Neurogenesis in olfactory epithelium: loss and recovery of transepithelial voltage transients following olfactory nerve section. J Neurophysiol 45:516-528. 
Sklar PB, Anholt RRH, Snyder SH (1987) The odorant-sensitive adenylate cyclase of olfactory receptor cells. Ann NY Acad Sci 510:623626.

Suzuki N (1987) Voltage-dependent conductances in solitary olfactory receptors cells. Ann NY Acad Sci 510:647-648.

Trombley PQ, Westbrook GL (1990) Excitatory synaptic transmission in cultures of olfactory bulb. J Neurophysiol 65:598-606.
Trotier D (1986) $\Lambda$ patch-clamp analysis of membrane currents in salamander olfactory receptor cells. Pfluegers Arch 407:589-595.

Trotier D, MacLeod P (1987) The amplification process in olfactory receptor cells. Ann NY Acad Sci 510:677-679. 